\title{
THE CONCLUSION OF THE DEDUCTION OF TASTE IN THE DIALECTIC OF THE POWER OF JUdGMENT AESTHETIC IN KANT
}

Manuel Sánchez ${ }^{1}$

\begin{abstract}
In this paper, it is argued that only in the section on dialectic in the Critique of Judgment does Kant reach a definitive and conclusive version of deduction, after discovering the concept of the supersensible. In the section on the deduction of pure aesthetic judgments, Kant does not satisfactorily explain the critical distinction between the sensible nature of humanity and the supersensible nature of human reason presupposed in the concept of universal communicability. While the concept of the supersensible illustrates this distinction, it is only through this concept that Kant that can justify the specific possibility of claiming subjective validity in taste. The priority of the solution found in the dialectic is illustrated not only by a comparative analysis of the two sections, but also by a historical reconstruction of the process of the formation of the work, which shows that the first formulation of the concept of validity coincides with the use of the concept of the supersensible.
\end{abstract}

KEYWORDS: Kant, Judgment, Critique of Judgment, Deduction, Judgment of Taste, Dialectic, Supersensible.

\section{Introduction: deduction and dialectic in the CritiQue of the Power OF JUDGMENT}

According to the explanation itself by Kant in the Critique of the Power of Judgment, the relevance of a dialectic in this work is due to the antinomy that arises in taste with respect to the principles of this faculty (KU, AA 05: 337). Therefore, the concept of dialectic is not applied strictly to the capacity of taste but rather to "[...] the critique of taste [...] with regard to its principles" (KU, AA 05: 337). This antinomy is brought out by the contradiction between two statements - thesis and antithesis - which describe two general positions relative to the comprehension of aesthetic experience and to sense, as the principles that account for this dichotomy should be termed.

\footnotetext{
${ }^{1}$ Depto. de Filosofía - Universidad de Granada, Espanha -e-mail: manuel_sanchez_rodriguez@yahoo.com
} 
The thesis is formulated by Kant as follows: "The judgment of taste is not based on concepts, for otherwise it would be possible to dispute [disputiren] about it (decide by means of proofs" (KU, AA 05: 338). The antithesis, on the contrary, affirms that "[the] judgment of taste is based on concepts, for otherwise, despite its variety, it would not even be possible to argue about it (to lay claim to the necessary assent of others to this judgment).” (KU, AA 05: 338s.).

It is true that Kant presents the Dialectic as a new section of the overall work and a later stage in the development of the transcendental critique of taste, which will follow the Deduction of pure aesthetic judgments, in which an explanation and justification is provided for the possibility of their principles and the sense in which we should understand them. However, the exposition of the problem of antinomy in the opening of the Dialectic appears from the beginning to be an extension of the same issue that Kant had already treated in the Analytic of the Beautiful, and to which (i.e. the issue) in principle he had already offered a definitive solution with the argument that we find from paragraphs 34 to 39 of the Deduction section.

It is undeniable that Kant defends the newness of the Dialectic within the general context of the work. However, we should ask ourselves whether the specific features that outline the problem of antinomy are not already present in the Analytic of taste and in the Deduction. Firstly, according to Kant, for the capacity to judge to be dialectic, this faculty must be rationalistic [vernüftelnd] —that is, judgments should a priori claim for universality ( $K U$, AA $05: 337)$. But this feature of judgments of taste is the main aim of the Second and Fourth Moment of the Analytic of the Beautiful, where the beautiful is explained as what pleases in a universal way without any concept, and it was illustrated as the exemplary case of a universal law that, however, cannot be adduced. In both cases, it furthermore encompassed part of the problem of antinomy: both the absence of a determinant concept as well as the impossibility of adducing a universal law. Secondly, in $\$ 31$ (KU, AA 05: 280s.), Kant explained the claim to universality a priori manifested in the judgments of taste such as reason that justifies the need of a deduction of this faculty; now, this same reason causes the aesthetic judgment to be dialectic (KU, AA 05: 337), while it is a capacity that can be rationalistic. Thirdly, Kant clarifies in $\$ 55$ of the work that the contradiction that gives rise to the dialectic does not emerge so much in taste itself, in which each individual declares a personal judgment without seeking to convert that 
particular position into a universal rule. Rather, the transcendental critique is concerned only with a dialectic regarding the critique of taste (not taste itself) in relation to its principles ( $K U$, AA 05: 337). It might appear that this marks the difference in the aim of the new section with respect to the preceding sections (PETER, 1992, p. 157s), but the explanation of this declaration does not indicate any novelty, either. According to Kant, the fact that the dialectic affects the transcendental critique of taste, and not taste itself (which is eminently a critical faculty of discernment), is because, "[...] mutually conflicting concepts of the basis of the possibility of judgments of taste naturally and unavoidably emerge" and because there is "[...] an antinomy of the principles of this faculty, which makes its lawfulness and hence also its inner possibility doubtful." (KU, AA 05: 337).

However, in the prolegomenon to the deduction, it is already clarified that the transcendental critique of taste does not coincide with the critique that taste delivers (as the critical faculty of the individual), since only the former is dedicated to investigating the conditions of possibility of this faculty while leaving aside the problem of the rules or precepts that could or should guide the personal good taste of the individual. The transcendental critique, as clarified in $\$ 34$, seeks to deriver "[...] the possibility of such a judging (i.e. taste) from the nature of this faculties as faculties of cognition in general" that is, the imagination and understanding - in such a way that it could and should "[...] develop and justify the subjective principle of taste as an a priori principle of the power of judgment" (KU, AA 05: 286). Thus, not just the dialectic but also the critique of taste concern only the problem of this faculty in relation to its principles and address this question showing in what sense we should understand such principles.

Regardless of whether the Dialectic provides new ideas in the development of the transcendental critique of taste and in the conceptual construct of the work, it is true that in this section Kant considers that problems previously dealt with in a programmatic way in the argument of the deduction remain open despite that the argument at first appeared to definitively resolve such problems. The Deduction should have justified the possibility of the subjective principles of taste which sustain the claim for universality that a priori demonstrates this faculty. In fact, Kant himself admits that the two opposite poles and their contradictions that define the problem of antinomy coincide with "[...] the two peculiarities of the judgment of taste represented above in the Analytic)" (KU, AA 05: 339), despite that the argument of the deduction appeared to be intended to 
clarify definitively any apparent contradiction between the two particularities, on explaining precisely how we should a priori interpret the principles underlying the aesthetic experience of taste. The first of these peculiarities coincides with the principle formulated in the antithesis of antinomy: "The judgment of taste determines its object with regard to satisfaction (as beauty) with a claim to the assent of everyone, as if it were objective." (KU, AA 05: 281s.). The second peculiarity of the judgments of taste corresponds to the principle expressed in the thesis: "The judgment of taste is not determinable by grounds of proof at all, just as if it were merely subjective." (KU, AA 05: 284). If the difference of the Dialectic with respect to the section of the Deduction is that the first one attended in particular the contradiction between the two different ways of considering the fundaments of the possibility or principles of taste, it appears clear that this contradiction had already been formulated in the section of the Deduction, and that the argument presented there should have sufficed to solve or clear up that problem, as Kant himself recognized at the end of $\$ 31(K U$, AA 05: 281).

Thus, it can rightfully be asked why in the section of the Dialectic both particularities of taste continue to be presented as open questions in the thesis and in the antithesis: why do they still appear to need, according Kant, a resolution [Auflösung] which, also according to Kant, should have been offered in the argument of the deduction presented from $\$ 34$ to $\$ 38$ ? With respect, for example, to the problem designated with antithesis, the argument of the deduction appeared to be sufficient in principle to explain the possibility of claiming universal communicability in the judgments of taste, and with it the sense in which to understand the possibility of arguing [Streit] about differences in taste. Kant himself had presented the argument of the deduction as a conclusive explanation for the possibility of our "hope" or claim "[...] to try to bring [...] unanimity in judgments through their mutual opposition", even though in judgments of taste no "[...] objective concepts as grounds of the judgment can be assumed" ( $K U$, AA 05: 338). Nevertheless, it should be noted that the above-cited texts belong to the explication of antinomy and are adduced as questions that have still not been clarified at all. The conclusion of the deduction in $\$ 38$ stated: “[...] the correspondence of a representation with these conditions of the power of judgment must be able to be assumed to be valid for everyone a priori" (KU, AA 05: 290), even while hope of genuine agreement of others with the isolated judgment of an individual's taste could be demonstrated a posteriori as having failed in the experience of a discussion on questions of taste. Now, if the conclusion of a deduction which is "so easy" 
( $K U$, AA 05: 290) had to be valid as a universal and necessary principle, why then does Kant still present this problem in the Dialectic as an open question, which remains to be resolved by the transcendental critique of taste, in this case by the dialectic of this critique?

In this paper, it is argued that Kant proceeds in this way because at the time of writing the section of the Deduction, he still considered the foundation for the subjective principle of taste and the comprehension of subjective validity derived from this principle to be definitive results of the work. If, on the contrary, Kant had already then reached the interpretation of the validity of taste according to the concept of the supersensible before finishing the drafting of the deduction argument found in $\$ \$ 34-38$, then he would likely have incorporated the concept in this version of the argument or at least he would not have again posed the same problem so redundantly in the Dialectic section. Clearly, this hypothesis stems from different suppositions which this work is meant to justify. First: Kant had not yet linked the concept of the supersensible with the solution of the problem of deduction when he wrote $\$ \$ 30$ to 40 of the work; moreover, he rejected such linkage. Secondly, after reaching this discovery and incorporating the concept of the supersensible into the discussion of taste, he reached the point of considering it as the final condition of possibility of the subjective validity of the judgments of taste and, therefore, as the final fundament on which the deduction argument should rest. That is, after linking the problem of validity of taste to the concept of the supersensible, Kant no longer believed that the first version of the deduction offered a conclusive argument to explain such a problem. Thirdly, despite this correction in the meaning of his own work, which took place in the very drafting process, Kant did not revise, complete, or correct the first version; instead, he added the new version of the deduction in the Dialectic section that he had last penned, where the concept of the supersensible certainly also served a function in the general framework of the systematics problem of the unity of theoretic reason and practical reason.

2 The PRESUPPOSITION OF THE DIFFERENCE BETWEEN THE SENSIBLE NATURE AND THE SUPERSENSIBLE NATURE OF HUMANITY IN THE CONCEPT OF UNIVERSAL COMMUNICABILITY

The principle purposiveness without an end expressed in the Analytic and in the argument of deduction describes the way in which we 
should understand the reciprocal relationship between the faculties that is presupposed in general for knowledge. However, it is necessary to appreciate that this principle does not designate a specific psychological relationship which must be presupposed in general in the judging, and which would be the feature that enables cognition of the object in general. Rather, as a subjective and transcendental principle referring to the relationship between faculties, the purposiveness is an idea, to which the faculties of cognition should accommodate in their psychological relationship when claiming cognition in general in a particular judgment.. Regardless of the psychological relationship in a given act of reflecting power of judgment, this judging should aim at this idea if the aspiration is universal validity. In the beautiful, the subject does not feel so much the psychological play between the imagination and understanding but rather the universality of this idea (KU, AA 05: 289), to which the inner activity presupposed in any psychological relation between faculties should a priori be aimed - that is, the harmony or free coincidence of these faculties that should be presupposed in general wherever knowledge of the object in general is sought:

[...] it can readily be seen that in a merely reflecting judgment imagination and understanding are considered in the relation to each other in which they must stand in the power of judgment in general, as compared with the relation in which they actually [wirklich] stand in the case of a given perception. (EE, AA 20, 220, cursive of the author). ${ }^{1}$

Thus it is not the pleasure but the universal validity of this pleasure perceived in the mind as connected with the mere judging of an object that is represented in a judgment of taste as a universal rule for the power of judgment, valid for everyone. It is an empirical judgment that I perceive and judge an object with pleasure. But it is an a priori judgment that I find it beautiful, i.e., that I may require that satisfaction of everyone as necessary. (KU, AA 05: 289).

\footnotetext{
${ }^{1}$ On the contrary, in his epistemological interpretation, Guyer (1979, p. 302-307) starts from the idea that taste is based on a certain state of mind of the gnosiological or even psychological type. In relation to the theme treated in the present paper, Guyer defends the thesis that in the Dialectic no revision is made of the result of the argument of the deduction presented in the Analytic, but rather that Kant introduces the concept of the supersensible in the development of the work merely with the aim of adducing a conclusive metaphysical argument against scepticism (1979, p. 294-309). A counter interpretation is found in R. Brandt (1989a; 1989b), according to whom the Dialectic is a place where the concept of communicability finds its final fundament and where the conclusion of the argument of deduction should be sought. The present work begins from this latter interpretation, though I do not agree with Brandt in his thesis that this was Kant's initial plan on writing the Analytica; as reflected here, Kant did not link the concept of the supersensible with the problem of taste when addressing the argument of deduction in the Analytic.
} 
Roughly sketched, Kant's argumentation can be reconstructed as follows: If on judging a representation a sentiment of universal communicability wells up in the spirit of a subject, without the power of judgment being guided by an determinant objective concept and without being influenced by a sensation, then this can only be because the subject feels the universal validity of judgment as a higher faculty of knowing. That is, the subject feels that others possess the same faculty of knowing as he/she self presupposes with his/her act of judging. This is "[...] that subjective element that one can presuppose in all human beings (as requisite for possible cognitions in general)" ( $K U$, AA 05: 290). From this argument, we can conclude only that the subject, experiencing the beautiful, feels and presumes that everyone else has the same faculty of judging that he or she ascribes to him/herself and the sentiment to which it is linked. But it is not possible to conclude that in fact each person possesses this faculty or that we are justified in expecting this concordance among the different humans to be ensured a priori. The argument has not demonstrated that this accord exists between individuals. Nevertheless, this idea appears to be presupposed in Kant, though not demonstrated, in the note at the end of $\$ 38$ :

In order to be justified in laying claim to universal assent for judgments of the aesthetic power of judgment resting merely on subjective grounds, it is sufficient to admit: 1) In all human beings, the subjective conditions of this faculty, as far as the relation of the cognitive powers therein set into action to a cognition in general is concerned, are the same, which must be true, since otherwise human beings could not communicate their representations and even cognition itself [...]. (KU, AA 05: $290 \mathrm{n})$.

In this way, we find that the deduction rests ultimately on the presupposition of the necessary communicability of theoretic cognition in general, which therefore also must be submitted to subjective conditions, the subjective conditions of this communicability without which this cognition would not be possible. We can presuppose this communicability because, if not, we could not justify the possibility of knowledge in general. This conception is adopted by Kant in a fundamental way in $\$ \$ 9^{\prime}$ and 212 of the

\footnotetext{
${ }^{2}$ In this text, Kant regards the feeling of the beautiful as the expression of a certain proportion in the relation between the faculties of knowing: "But this disposition of the cognitive powers has a different proportion depending on the difference of the objects that are given. Nevertheless, there must be one in which this inner relationship is optimal for the animation of both powers of the mind [...] with respect to cognition [...] in general." (KU, AA 05: 238s). However, a psychologist interpretation of Kant's argumentation cannot be built from this text. In the same paragraph, he warns that it is not
} 
work. In $\$ \$ 21$ and 22 he introduces the concept of common sense as underlying the communicability expressed in the judgments of taste, without delving into the nature or origin of this "ideal norm" of taste with respect to the system of reason. Moreover, in $\$ 22$ he clearly explains that the solution of this question should be treated in another place in the work (KU, AA 05: 239s.).

Therefore, these arguments do not explain the type of universal communicability of taste nor the origin of the idea of common sense presupposed in this communicability.3. The connection of this conception with the theoretic sphere is manifest, but it also results from Kant's explanation that the meaning of these concepts does not come simply from the founding of theoretic cognition and the objective-determining conditions of the understanding that takes place in the first Critique. Furthermore, Kant not only in general presupposes universal communicability as the underpinnings of taste but rather a certain type of communicability. Thus, he takes this concept as the claim for universal subjective - or intersubjective - validity of taste. Now, in the section of the Deduction, he offers no foundation at all for this claim; this is only presupposed as the subjective condition of knowledge, without clarifying or justifying the legitimacy of this condition by explaining its origin within the framework of pure reason. In fact, that this concept of validity must be presupposed in the reflecting use of the power of judgment for cognition in general does not mean that this concept is a secondary derivative of the concept of objective validity of cognition in general. Rather, it signifies that the theoretic use of reason also presupposes subjective conditions, which are explicit by the analysis and critique of judgments of taste, and that they have their origin in the rational concept of the supersensible, for which theoretic reason and practical reason are found to be connected in an undetermined and unknown way by mediation of reflecting power of judgment. Now, this systematic conception, presented by Kant in the Introduction of the work ( $K U$, AA 05: 176), has not been elaborated upon even by him at the time of writing the Deduction. However, although in the Deduction Kant did not yet reach the concept of the supersensible, his comprehension of universal communicability already presupposes a differentiation between the sensible

this communicability derived from a particular state of mine that serves as a fundament to the feeling, but rather common sense underlies this communicability: "since the universal communicability of a feeling presupposes a common sense, the latter must be able to be assumed with good reason, and indeed without appeal to psychological observations, but rather as the necessary condition of the universal communicability of our cognition [...].” (KU, AA 05: 239).

${ }^{3}$ Cf. BRANDT (1989a, p. 188s). 
nature and the supersensible or intelligible nature of humanity. It will be the critical delving into this presupposition, within the framework of the transcendental system of reason, which will lead him to the concept of the supersensible.

When a subject discusses questions of taste, this person seeks the approval of the others only under the condition that the possibility of their disagreement is conceded. Hence the subject should acknowledge for the other the same autonomous and formal faculty of judging that he/her ascribes to him/herself with his/her own act of judging. When Kant speaks in $₫ 38$ of the subjective element that must be presupposed in all human beings, he cannot be referring to the psychological or physiological nature in which all humans coincide, as the aforementioned universal communicability is not based on the sensible nature of humanity. When, by a judgment of particular taste, universal approval is sought, such judgment of taste does not thereby reflect the true and successful concordance with the universal nature of human sensibility. If this were the case, then the judgments of taste would express the universality of the sensible nature of humanity and the communicability of the feeling that would come from a psychological type of concordance, which all sensible beings would share in this regard. A real difference in questions of taste would therefore be impossible.

However, this description does not correspond to the type of communicability that occurs in questions of taste, as this conception is described in the Critique of the Power of Judgment.. With respect to taste, we can never draw the conclusion that others will share our particular judgment. For this reason, the failed judgment of the bad poet concerning his own work is universally valid and implies the communicability of his judgment with equal right as the judgment of the most successful and acclaimed poet of the period. Both, when they express their judgment of taste and feel that any other should (sollte) agree with their view, they ideally refer to the same autonomous faculty of the judging of the others and to the dignity of any possible viewpoint. If the goal of the judgment were the whole of existing human beings (the sensible nature of humanity), then only the judgment of successful taste would be universally valid in the pursuit of universal communicability. However, the judgment that is demonstrated a posteriori as failed is, according to Kant, equally valid in a universal way, precisely because it claims for universal communicability. ${ }^{4}$

${ }^{4}$ In this regard, see WIELAND (2001, p. 243-57). 
Communicability of feeling in the judgment of taste is based on the possibility of communicability among human beings as rational beings, insofar as this is based on an idea underlying this communicability - that is, the hope "[...] to bring unanimity in judgments [...]" (KU, AA 05: 338), or the aspiration of casting light on disputes of taste "[...] through their mutual opposition" ( $K U$, AA 05: 338). The accord of the human beings that is presupposed in the debates on taste arises in reality from the idea of universal human reason, as Kant argues in his analysis of the concept of sensus communis. Therefore, taste rests on common or universal sense insomuch as this concept is considered to be an ideal norm of reason. In $\$ 22$, this norm is described as a principle or idea, which should be "[...] interpreted as subjective-universal" ( $K U$, AA 05: 239), even when here the unresolved question remains concerning whether this idea "[...] is in fact only a demand of reason to produce such a unanimity in the manner of sensing, [...] and the judgment of taste only provides an example of the application of this principle" (KU, AA 05: 240). ${ }^{5}$ In $\$ 40$, sensus communis is defined in the following way:

\begin{abstract}
By "sensus communis", however, must be understood the idea of a communal sense, i.e., a faculty for judging that in its reflection takes account (a priori) of everyone else's ways of representing in thought, in order as it were to hold its judgment up to human reason as a whole and thereby avoid the illusion which, from subjective private conditions that could easily be held to be objective, would have a detrimental influence on the judgment. (KU, AA 05: 293).
\end{abstract}

Both in $\$ 38$ and in the texts that we have examined before ( $\$ \$ 9$ and 21 ), we find a reference to the subjective conditions of universal communicability of knowledge in general that should be presupposed in all human beings, without Kant's delving into the meaning of such conditions. Certainly, in $\$ 40$ he brings up the concept of the totality of human reason as a regulatory idea for sensus communis. This text, however, does not even actually deal with the argument of deduction nor furthermore does it clarify the fundament that allows a connection, at the systematic level, with the claim to universal validity

\footnotetext{
${ }^{5}$ This declaration of the Analytic of the Beautiful in $\$ 22$ appears to refer to the solution offered in the Dialectic, in such a way that Kant would already have sketched the solution posed in this section. Nevertheless, the same statement of the problem in $\$ 22$ differs in the essential aspect of the solution defended in the Dialectic. In the first text, Kant refers to the hypothetical rational demand of universal adherence in terms of a duty marked by the "objective necessity of the confluence of the feeling of everyone with that of each" (KU, AA 05: 240). However, in the Dialectic, the concept of the supersensible, though of rational origin, will be defined as subjective and indeterminate.
} 
of taste with reason, in such a way that it can be understood why judgments of taste do not refer to the sensible nature that all humans in fact share, but rather to their supersensible and rational nature, of which every human being ideally partakes. ${ }^{6}$ Individuals as a whole do not constitute "human reason as a whole", although each individual - considered as an supersensible subject — partakes of human reason as a whole. ${ }^{7}$ In this way, the particularities of taste pointed out by Kant, as well as the antinomy of the critique of this faculty can be clarified only if it is understood that in the judgment of taste the sensible experience of others is not taken into consideration on the basis of a determinant concept in the objective sense. Nor is the sensible and genuine concordance among human beings reflected, but rather this has as its fundament the supersensible nature of humanity. Only the critical demarcation between the sensible nature and the supersensible nature of the human being can uphold a justification of the claim of universal validity of taste. However, in the Analytic of the Beautiful, Kant still does not adduce the concept of the supersensible as the fundament of universal communicability, nor guarantees the possibility of a connection between taste and reason.

Given that this concept is not used in the chapter dedicated to deduction, it must be assumed that the elaboration of the argument had not reached such a state of maturity when Kant wrote that section of the work. It is possible that he would only later pose the systematic connection of taste with the concept of the supersensible, by which he would arrive at the conclusion that the argument of $\$ 38$ was not really conclusive in light of the intellectual development undergone. This could well be the reason why Kant

\footnotetext{
${ }^{6}$ In this lies an important difference between the Critique of the Power of Jjudgment and the first aesthetic plan by Kant at the beginning of the 1770s. Under the influence of the theory of sensible cognition of the Dissertatio, Kant then conceived of the beautiful as an expression of the concordance of the representation with the universal and formal laws of sensibility that make the constitution of the phenomenon possible and that are truly shared by all humans as sensible beings. For this reason, Kant begins in his argumentation exclusively from the successful judging of taste, considering that only such successful judgments are universally valid, since all humans should agree with them on the basis of the common structure of sensitivity. This posture, ultimately, could only lead Kant to evade the aesthetic problem, rejecting the possibility of divergences in questions of taste that are not merely apparent: "My judgment on what is beautiful, when I am right in calling something beautiful, should also be valid for others [...]. All judgments of taste are universally valid according to the laws of sensibility." (V-Anth/Parow, AA 25: 389s., cursive of the author; also see p. 377s.). "The judgments of the beautiful are directed at the object; hence, they have universal validity. In the judgments on an object, two cannot contradict each other. What one judges in the object has a universal validity. Therefore, if one says that the thing is beautiful and another that it is ugly, then at least one must have said something false." (V-Logik/ Philippi, AA 24: 350).
}

${ }^{7}$ On the idea of universal human reason, see HINSKE (1980, p. 31-60). 
again poses the problem of deduction in the section of the Dialectic, where he would delve into the systematic meaning of the concept of purposiveness with the help of the concept of the supersensible. Below, we focus on these ideas.

\section{The SOlution of an antinOMY of taste as the CONCLUSion of the DEDUCTION}

It appears that, when Kant wrote the chapter dedicated to the Deduction, he still rejected - in contradiction with the future solution of antinomy- that the supersensible could be the fundament for the communicability of taste. This is clearly observed in $\$ 39$. According to Kant, the communicability in sensus communis is differentiated from the communicability of pleasure related to the sublime, precisely in that the sublime "[...] presupposes another feeling", "[...] which, no matter how obscure it might be, has a moral foundation" (KU, AA 05: 292). It would be absurd to affirm that Kant would here reject the concept of the supersensible as the fundament of communicability of taste if he had already reached and outlined the conception expressed later in the Dialectic, where the communicability rests precisely on the concept of the supersensible. ${ }^{8}$ This is an idea that Kant emphasizes in the Dialectic: without this concept "[judgment] could not lay claim to necessary validity for everyone at all" (KU, AA 05: 339); or, "[...] if one did not assume such a point of view, then the claim of the judgment of taste to universal validity could not be saved" (KU, AA 05: 340). If we do not begin with the difference between the sensible and the supersensible, we would be forced to admit, as Kant himself did in his first aesthetic plan, ${ }^{9}$ that

[...] a judgment of taste deserves to be held to be correct only insofar as it happens that many people agree about it, and even this, strictly speaking, not because one suspects an a priori principle behind this consensus, but rather (as in the taste of the palate) because the subjects are contingently organized in the same way. (KU, AA $05: 345 s)$.

The concept of the supersensible in the dialectic leads to a clear rejection of the possibility that the beautiful is an expression or reflection of a concordance of the sensible nature of humanity. On the other hand, the indeterminate, even mistaken, conception of communicability in the final note of $\$ 38$ does not yet exclude the possibility that its fundament lies in a universality

\footnotetext{
${ }^{8}$ As presupposed in the interpretation of BRANDT (1989a, 1989b).

${ }^{9}$ In this respect, see note 7 in this work.
} 
or generality of the empirical, psychological, physiological, or gnosiological type, which would have to be constitutive of human nature: "In all human beings, the subjective conditions of this faculty, as far as the relation of the cognitive powers therein set into action to a cognition in general is concerned, are the same, which must be true, since otherwise human beings could not communicate their representations and even cognition itself." (KU, AA 05: $290)$. In this regard, $\$ 39$ raises a contradiction with the theory explicated in the Dialectic, inasmuch as it expressly rejects the possibility that the concept of the supersensible could be the fundament of the communicability of taste. As revealed by his own declaration, at this time, Kant thought that this concept had moral underpinnings and was based on concepts - determinant and objective - of practical reason. Therefore, we might plausibly infer that Kant still conceived of the concept of the supersensible only from the perspective of the Critique of Practical Reason and had not yet discovered its subjective and heautonomous meaning.

When confronting these divergences between the different parts of the third Critique, we should take into account that these divergences reproduce, in the same text, an evolution or even variation that occurs at the historic level in the very process of composing the text. Thanks to the historical-philological study by Giorgio Tonelli (1954), we know today that Kant did not write the work according to a linear unitary plan. Rather the contrary, from 1788 to 1790 , he developed intellectually with respect to the scope, structure, terminology, and systematic placement of the work within the general framework of criticism. From the historical arrangement of the different sections of the work proposed by Tonelli, we can posit that Kant used the concept of the supersensible only after writing the chapter dedicated to deduction. If we add the fact that he did not send the manuscript to press all at once but rather in separate groups, after composing different chapters or groups of paragraphs, it becomes possible to understand why the aforementioned variation of the Dialectic, after he reformulated his argumentation according to the concept of the supersensible, did not move him to revise or correct the previous chapter, where we find the first version of the argument of deduction. Instead, Kant again simply poses the same question in the section of the Dialectic, with the intention of delving into the fundament of the argument by way of the concept of the supersensible.

This historical variation among the different sections of the Deduction and the Dialectic can also be perceived from the Reflexionen from the 
posthumous writings of the corresponding stages. In the Refl. 988 (c. 1784), we find a preliminary draft of the deduction, along the lines of transcendental criticism of taste:

When the subject refers to the object [...], but no particular concept on any object nor on any determinable relations ( $\mathrm{g}$ of the concept) with the subject makes the judgment necessary, then [this judgment] should be referred to the object in general by the force of spirit of knowledge in general. In such a case, there is no specific concept but rather merely the feeling of movement of ( $\mathrm{g}$ all) the cognitive powers, capable of being communicated by concepts in general, which contain the fundament of judgment. (Refl. 988, c. 1784, AA 15: 432).

The fundament of taste resides here in the psychological movement or activity of the cognitive powers for knowledge in general, which is felt as communicable in the mood of the subject. If cognition in general has a motive, Kant holds in the same Reflexion, it follows a priori "by itself" that this will prompt communicable pleasure in the mood of the subject $(K U$, AA 15: 433). It is true that in the text he does not yet mention the concept of purposiveness - as in the Analytic and in the Deduction. However, Kant already defends the thesis that pleasure consists of the communicability of the psychological activity involved in cognition in general, in accord with the general conception explicated in $\$ \$ 9,21$, and 38 . The concept of the supersensible does not appear in the text.

This early sketch is revised later in Refl. 992 (between 1787 and 1790). The form of argumentation presents clear parallels with respect to Refl. 988, but with the noteworthy exception that Kant speaks for the first time in particular on the "supersensible determination" of the cognitive faculties, as opposed to the their sensible determination. There, we find a judgment that is declared to be valid for anyone, without adducing empirical or a priori proofs to ensure such concordance:

Then its $[\ldots]$ representation $[\ldots]$ refers to a principle $[\ldots]$ of supersensible determination [...] of our cognitive faculties. Thus, if judgment must have universal validity, then there must be a principle; given that there is no possibility of a fundament of demonstration, nor any rule for the use of understanding or of reason in relation to objects of the senses, then there must be a principle for the $[\ldots]$ use of the cognitive faculties $[\ldots]$ which fuses $[\ldots]$ in any $[\ldots]$ supersensible determination $[\ldots]$ or refers to it $[\ldots]$; 
in this way, only in relation to [this principle] can such a judgment please. (Refl. 992, 1787-1790, AA 15: 436).

The pleasure related to the beautiful does not reflect nor express a psychological and communicable relationship of cognitive powers but rather the supersensible determination of this relationship, on which it is based or to which it refers. If we start with the chronological order of writing the work as offered by Tonelli (1954, p. 431-45), then this reflection should belong to the period in which Kant was occupied with composing the Dialectic or the First Introduction, given that the text contains the expression "supersensible determination", which in $\$ 39$ is excluded as the fundament of the communicability of taste. Also, Refl. 992 speaks of a deduction "on the sublime of nature" (AA 15: 437), which finally will not find a place in the section devoted to the sublime and written after the Dialectic. All told, the concept of the supersensible is not used in the text to pose the problem of the antinomy of taste; rather, this is a new version of the first draft of a deduction of the judgment of taste.

This revision is evident in the section of the Dialectic. Firstly, Kant here presents the supersensible as the fundament for the principle of purposiveness without an end, which in the section of the Deduction was still considered the ultimate principle of taste.

But now all contradiction vanishes if I say that the judgment of taste is based on a concept (of a general ground for the subjective purposiveness of nature for the power of judgment), from which, however, nothing can be cognized and proved with regard to the object, because it is in itself indeterminable and unfit for cognition; yet at the same time by means of this very concept it acquires validity for everyone [...], because its determining ground may lie in the concept of that which can be regarded as the supersensible substratum of humanity. (KU, AA 05: 340).

Secondly, Kant himself refers explicitly to the argument formulated in $\$ 57$ under the term "deduction".

But if it is conceded that our deduction is at least on the right track, even if it has not been made clear enough in every detail, then three ideas are revealed: first, that of the supersensible in general, without further determination, as the substratum of nature; second, the very same thing, as the principle of the subjective purposiveness of nature for our faculty 
of cognition, third, the very same thing, as the principle of the ends of freedom and principle of the correspondence of freedom with those ends in the moral sphere. (KU, AA 05: 346).

In relation to this text, we should not conclude that Kant uses the term "deduction" to refer to the argument presented previously in the Analytic. The conclusion of the argument laid out in that text reflects a conception completely foreign to the Analytic, as in it no reference is made to differentiation in the way of thinking with respect to the supersensible in relation to theoretic reason, power of judgment, and practical reason. On the contrary, in $\$ 39$ the idea of the supersensible fits only in the moral sphere and, by extension, in that of the aesthetic sentiment of the sublime.

On this basis, Kant considers the solution of the antinomy of taste to be the deduction of the final principle of this faculty. Only by laying the fundaments of the judgment of taste from the concept of the supersensible nature of humanity and of the critical differentiation between the sensible concordance of the human beings and the supersensible concordance of human reason as a whole can Kant simultaneously explain the possibility of the validity of taste and dissolve the antinomy of this faculty. Exclusively by the rational and subjective concept of the supersensible can the critique explain the beautiful as a morally good symbol and ensure the claim to validity in the judgment of taste: "Now I say that the beautiful is the symbol of the morally good, and also that only in this respect (that of a relation that is natural to everyone, and that is also expected of everyone else as a duty) does it please with a claim to the assent of everyone else [...]" (KU, AA 05: 353, cursive of the author).

In fact, from the investigation presented in this paper, it should be concluded that Kant even reaches the point of presenting excuses for having finally reached a solution to the deduction after following the path of this argument somewhat obscurely in its different stages: "But if it is conceded that our deduction is at least on the right track, even if it has not been made clear enough in every detail [...]" (KU, AA 05: 346).

The final argument of the deduction does not imply so much a correction with respect to the first version but rather a profound examination, which would enable the presuppositions of this first version to be explained in order to elucidate the conditions surrounding the possibility of claiming subjective validity that is manifested in taste and which, though originating 
in reason, cannot be explained from the objective-determining fundaments of reason, whether in the theoretic or moral realms.

SÁNCHEZ, Manuel. A conclusão da dedução do gosto na dialética da faculdade de juízo estética em Kant. Trans/Form/Ação, Marília, v. 36, n. 2, p. 45-62, Maio/Ago., 2013.

RESUMO: Neste artigo, defende-se que, somente na seção da Dialética da Crítica do Juízo, Kant chega a uma versão definitiva e conclusiva do argumento da dedução, após descobrir o conceito de suprassensível. Na seção da Deduçáo do Juízo Estético, Kant não justifica de forma satisfatória a diferença crucial entre a natureza sensível da humanidade e a natureza suprassensível da razão humana, que é pressuposta no conceito de comunicação universal. Enquanto o conceito de suprassensível ilustra tal diferença, somente através dele pode Kant justificar a possibilidade de uma pretensão de validez subjetiva no gosto. Essa prioridade da solução que encontramos na Dialética é ilustrada não somente a partir de uma análise comparativa entre ambas as seçóes, mas também a partir de uma reconstrução histórico-evolutiva do processo de formação da obra, a qual mostra que a primeira formulação do conceito de validez coincide com o uso do suprassensível.

PALAVRAS-CHAVE: Kant. Critica do Juizo. Dedução. Juízo do gosto. Dialética. Suprassensível.

\section{REFERENCES}

BRANDT, Reinhard. The Deductions in the Critique of Judgment: Comments on Hampshire and Hortsmann. In: Kant's Transcendental Deductions and Critical Philosophy. Oxford and New York: Stanford University Press, 1989a, p. 177-190.

BRANDT, Reinhard: Analytik/Dialectic. In: Reading Kant. New Perspectives on Transcendental Arguments and Critical Philosophy. Ed. Eva Schaper and Wilhelm Vosenkuhl. Oxford and New York: Basil Blackwell, 1989b, p. 175-195.

GUYER, Paul. Kant and the Claims of Taste. Cambridge: Cambridge University Press, $1979 / 1997$.

HINSKE, Norbert. Kant als Herausforderung an die Gegenwart. Freiburg \& München: Karl Alber, 1980.

KANT, Immanuel. Kant's gesammelte Schirften. Berlin y Leipzig: Ed. de la Königlich Preußische Akademie der Wissenschaften und ihren Nachfolgern, 1902ss. (=AA)

KANT, Immanuel. Erste Einleitung in die Critique of Judgment. In AA 20 (=EE).

KANT, Immanuel. Kritik der reinen Vernunft. In AA 03 y 04 (= KrV). 
KANT, Immanuel. Kritik der Urteilskraft. In: AA $05(=K U)$. English version: KANT, Immanuel. Critique of the Power of Judgment. Cambridge, 2000.

KANT, Immanuel. Reflexionen zur Anthropologie. In AA 15 (= Refl.).

KANT, Immanuel. Vorlesung über Anthropologie Parow. In: AA 25 (=V-Anth/Parow).

KANT, Immanuel. Vorlesung über Logik Philippi. In: AA 24 (=V-Lo/Philippi).

PETER, Joachim 1992. Das transzendentale Prinzip der Urteilskraft. Eine Untersuchung zur Funktion und Struktur der reflektierenden Urteilskraft. Berlin \& New York: Walter de Gruyter, 1992.

TONELLI, Giorgio. La formazione del testo della 'Critique of Judgment'. Revue Internationale de Philosophie, 423-48, 1954.

WIELAND, Wolfgang. Urteil und Gefühl. Kants Theorie der Urteilskraft. Göttingen: Vandenhoeck \& Ruprecht, 2001

Recebido em: 17.09.2012

Aceito em: 26.11.2012 


\title{
O PEnSAMEnto de MarX \\ SOBRE A SUBJETIVIDADE
}

\author{
Eduardo F. Chagas ${ }^{l}$
}

RESUMO: O pensamento de Karl Marx sobre a subjetividade humana é pouco conhecido e divulgado na língua portuguesa, e, no Brasil, particularmente, carece ainda de um estudo amplo, explícito e sistemático. Meu artigo pretende esboçar uma reflexão mais completa de sua filosofia sobre a subjetividade humana, insistindo não somente na crítica, mas também, e especialmente, na compreensão da referida questão, a partir de uma leitura imanente e estrutural de suas obras, no original. Vale ainda ressaltar que minha investigação se apoia na conexão entre subjetividade e objetividade, entre sujeito e objeto, inquirindo se há um determinismo da objetividade sobre a subjetividade, ou seja, se essas duas determinaçōes são contraditórias no interior do pensamento marxiano, comprometendo, pois, as suas reflexóes acerca da crítica à filosofia especulativa de Hegel e ao empirismo da economia clássica, ou se, na verdade, tal conexáo é o segredo recôndito de sua filosofia sobre a subjetividade humana.

PALAVRAS-CHAVE: Marx. Subjetividade. Determinismo.

A questão da subjetividade no pensamento de Marx permanece, ainda hoje, amplamente inexplorada, sendo, inclusive, tratada, por determinadas correntes no interior do pensamento marxista, de forma preconceituosa, como uma questão secundária a ser desconsiderada. ${ }^{2}$ Alguns autores apontaram-na como uma deficiência, tendo em vista que, para estes, há na obra de Marx um forte traço economicista e determinista, à medida que ele compreende os mecanismos internos, as atividades da consciência, como um fenômeno secundário, mero reflexo das determinaçóes materiais, das relações de produção, inviabilizando, assim, uma reflexão rica e complexa sobre a subjetividade humana. Tais posiçóes se baseiam, de forma apressada,

\footnotetext{
${ }^{1}$ Doutor em Filosofia; professor da Graduação e da Pós-Graduação do Curso de Filosofia da Universidade Federal do Ceará (UFCE) e colaborador do Programa de Pós-Graduação da Faculdade de Educaçấo (FACED) da UFC. E-mail: ef.chagas@uol.com.br.

${ }^{2}$ Cf. SILVEIRA, Maria Lídia Souza da. Algumas notas sobre a temática da subjetividade no âmbito do marxismo. Revista Outubro, No. 7, p. 103, 2002.
} 